\title{
Make Peace With the Damaged Coast(The Experience of Mentok Coastal Community in Adapting the Offshore Tin Mining)
}

\author{
Ibrahim $^{1,1}$ Dwi Haryadi ${ }^{2}$, and Nanang Wahyudin ${ }^{3}$ \\ ${ }^{1}$ Political Science Department, Bangka Belitung University, Indonesia \\ ${ }^{2}$ Law Department, Bangka Belitung University, Indonesia \\ ${ }^{3}$ Management Department, Bangka Belitung University, Indonesia
}

\begin{abstract}
Tin mining in Mentok coastal area, West Bangka Regency has been the ironic view in the middle of local government effort to progress its territory, including the effort to develop tourism and marine sector. When there are many areas in Bangka Island flare up to refuse the presence of Production Suction Vessel (KIP/KapalIsapProduksi), people around Mentok coastal area spanning from Rubiah gulf to Kalian peninsula received the present of offshore mining. This paper went deep into why KIP could be accepted by Mentok people. It was designed from qualitative research result exploring data through deep interview technique, observation, and documentation. This study result showed that KIP operation in the area run well either as there was compensation modus distributed to every householder in the coastal area in the form of cash money. Provision of cash was managed in terms of securing production process assisted by the administrator to bridge the interest between businessman and society. Local government as the permission issuer and society who didn't give resistance omission sustainability and natural preservation principle; a pragmatic face wrapped with omission principle and justification on the economy aggression.
\end{abstract}

\section{Introduction}

Bangka Island is famous worldwide since long time ago with its production, along with the wellknown of pepper as the important world spice with the brand 'Muntok White Pepper' (see Heidhues, 2008: 4-9; Sujitno, 2007: 5-7; Susilo\&Maemunah, 2009: 10). Mentok is one of places having important history in this island civilization (see Susilo\&Maemunah, 2009: 15-16; Erman, 2009: 20-23). In addition to the entering gate from South Sumatera mainland, Mentok is also an initial place for tin mining occupied by Palembang sultanate. Until then Dutch government made this area into the biggest tin harbor in Bangka Island. No wonder, this area was known as the very important and strategic in this territory.

Along with the expansion of territory, Mentok that was initially a district, in 2003 developed into regency capital as well as West Bangka government center. As a regency capital, Mentok developed as a busy town with various activities; one that ogled was tourism sector development. Coastal area became the important mainstay of Mentok as it has a long and beautiful coastal line, supported by natural sea wealth, such as the fisherman catching, the passenger harbor for ship and ferry, loading and unloading harbor, as well as the harbor for tin ore reserves in the ocean.

In the middle of some local development growth, tin production temptation has become inseparable part of economical business. Tin regulation changing in national level has implicated to the regions since reformation started in 1998 (Rahman et al. 2011: 28-29; Yunianto, 2009: 100-101; Ibrahim, 2012: 68-78; Haryadi, 2014; 2015) and provided opportunity for mining to shift from on- to offshore and at the same time giving chance for private parties to develop offshore mining sector. Mentok coast territory spanning kilometers changed into offshore mining area, as if chasing with the development in other sectors, for example, the one in tourism, fishery, and minor fisherman catching.

\footnotetext{
${ }^{1}$ Correspondingauthor: iim_babel@yahoo.com
} 
Mentok with its coastal wealth changed its face. In land, Mentok taking coastal area as the busy place dressed up as capital regency; however in the ocean that is only 2-3 kilometers away, offshore mining ships were milling about as if competing with fisherman life and freight and passenger vessels. It is interesting to explore on how these two life sides walk side by side.

This writingrevealed the important fact on how the offshore mining ships as production suction vessel could operate and well accepted in Mentok coast area. Coastal people life are getting along well with the ocean peaceful, thatin fact, most of them are fisherman territory. The debate of environmental damage and coastal fisherman anxiety as a result of production suction vessel operation exploring tin employing non-environment friendly method as if to be double standard for the coastal society who were open and accommodative. Is it true if this condition is two sides of coin running each other in support or because there is access inequality wrapped up with pragmatism, this writing provided logical information.

\section{Research Method}

The method employed in this study was qualitative one. Qualitative method explores the data deepness to explain the study focus (Marsh \& Stoker, 2010: 242; see also Chadwick, et al., 1991: 234). Data collection technique was conducted by interview, documentation, and observation. Interview informants were chosen by using purposing sampling that was determining informants by certain considerations. Interview was chosen as major data exploration technique by consideration to give researcher discretion to explore information, view, and value from the field (see Casley\& Kumar, 1989: 11). In this regard, the chosen informant criteria were fisherman, housewife, production suction vessel administrator, businessman, and environment activist. The question in the interview was un-structured that was then situationally developed in the field with question lattice that had been already arranged before going to the field. Documentation was performed by searching other source data in the form of photograph taken in the field. Observation was conducted by performing direct observation to the research setting.

\section{Discussions}

\subsection{Mentok and Chronic Tin Mining}

Tin mining operating in West Bangka Regency coastal area has been generally a Production Suction Vessel (KIP/KapalIsapProduksi). Different with many other coastal areas in Bangka Island that are full with suction pontoon conventional tin mining and TI Rajuk, either legal or illegal (see Irawanet al., 2014), offshore tin mining in Mentok and surrounding has been in suction vessels. Production suction vessel is mostly a former tin mining boat in Phuket Thailand re-operated in Bangka Belitung Islands Province territory.

KIP operation got much controversy as generally it operates in shallow sea. In addition to freely moving outside the area, KIP operation also destroyed environment as it operates big boor/dredger functioning as suction as well as the separator between tin ore and sand in the ship. In many places, KIP received hard rejection from society (Ibrahim et al.,2018); however, in Mentok waters, KIP can freely operate.

Below are some pictures of KIP present and operation along the Mentok coast.

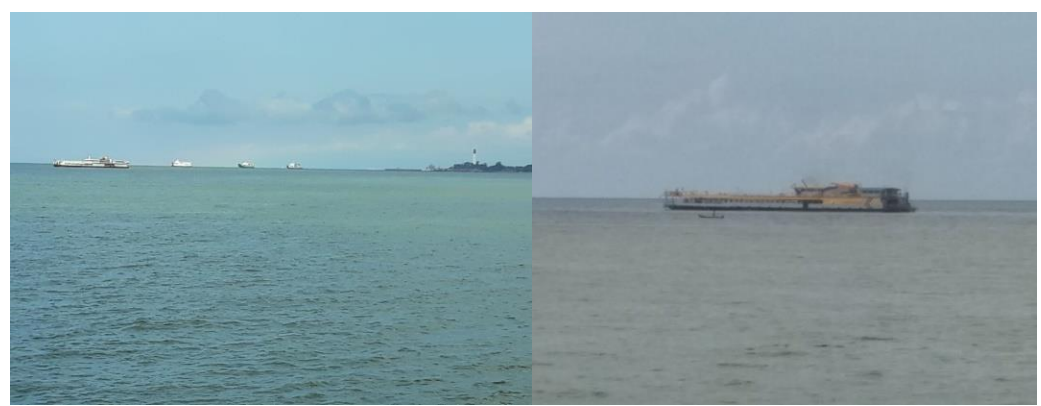

Fig 1. KIP in Mentok Coast 
Before 2014, KIP operation permission was issued by government with different authority detail from that of after 2014, using the stipulation as follows:

Table 1. Tin regulation and its permission authority

\begin{tabular}{|c|c|c|}
\hline $\begin{array}{c}\text { Before Regulation } \\
\mathbf{2 3 / 2 0 1 4}\end{array}$ & Permission Issue Authority & $\begin{array}{c}\text { After Regulation } \\
\mathbf{2 3 / 2 0 1 4}\end{array}$ \\
\hline$<4$ miles & $\begin{array}{c}\text { Regency/Municipality } \\
\text { Government }\end{array}$ & - \\
\hline $4-12$ miles & Provincial Government & $0-12$ miles \\
\hline$>12$ miles & Central Government & $>12$ miles \\
\hline
\end{tabular}

KIP operating in West Bangka Regency territory based on Mentok Head Harbor obtained from RMOL Babel (9/4/2018 edition) showed that there were more than 28 illegal KIP in which 25 operate in Jebus district, 2 KIP in TanjungUlarMentok district, and 1 in DLKP Mentok. All KIPs are owned by 7 different companies.

The tin produced inter location and inter KIP was relative different. In Mentok waters, tin production was more or less 10 drums (equal to 10 tons) in one unloading. This number was considered as low compared to other coastal areas that could reach 45 - 60 drums per unloading (Reza interview, 13/4/2018). Nevertheless, Mentok coast was relative preferred since it could be used as shelter in a bad weather, they could also operate.

KIP operations were basically indicated very destructive toward the environment (see Milieudefensie, 2016; Febriantoet al., 2015; Muslihet al., 2014). Its very flexible cruising range and its big production capacity made KIP as having critical notes for environment conservation movement. Edi Nayo, one of tourism activists (interview 13/4/2018) said that offshore mining in any form is definitely damaging. Coral reef damaged and sea biota decreased is one of impacts resulted from offshore mining. According to him, last time it was easy to find crab; however, recently it is difficult and even the dead fish stranded on the beach as a result of KIP mining. Agus, one of fishermen in the interview (13/4/2018) said that since there was KIP, his catching area was going further into the middle of ocean and the fish quality caught was not as expensive as before.

As the amends for KIP operation in Mentok waters, people around it obtain compensation as donation for every householder. The quantity is various; the average is $\mathrm{Rp} \mathrm{300,000/householder} \mathrm{monthly.} \mathrm{The}$ payment is performed through administrator having important role to bridge the interest between KIP management and coastal people. It's not surprising if KIP operation in Mentok waters is relatively abandoned and there's no meaningful rejection. Indeed, the interview result on site showed that one territory experience with another around KampungTanjung spanning across this Mentok coast was different. However, with the similar spirit, the conflict hushing was performed through compensation modus. This different was on communication pattern of KIP owner with society, compensation distribution pattern, until the compensation quantity.

Until this study was conducted, at least many KIPs leant back or ensconced and operated at once. While people activities also run, such as activities going to the sea for fisherman, material loading and unloading, ship passenger arrival-departure and tourism area development activities by local government in the coastal area: an ironic condition on the fact of coastal people life connected to complicated discussions in terms of exploitation, prosperity, empowerment, and sustainable development.

\subsection{Actor Map}

KIP was basically a big investment since bringing this kind of ship needed much money. The price for second hand ship was above 20 billion per unit. Besides that, skillful operator who understood with all equipment's used usually operated KIP. They were mostly from Thailand. It isn't surprising ifthe society narrative found a lot on site stated that foreign workers from Thailand dominating this KIP job. It means that mobilizing capital and labor resources is a costly project investment, not even its operation. Therefore, it could be mapped that the key actor in KIP mining business was the capital owner and big businessman. It can be ensured that there's no KIP owned by local people and small scale businessmen. Interestingly, according to Reza interview (13/4/2018), the businessmen do not want directly dealing with society. They preferred to involve certain party to bridge their interest in order not to get rejection from society. 
As mining business in coastal area and in large scale, it needs some procedures to get the license to operate. If it's noticed upstream, the permission issuance proceeded with the document accomplishment for analysis regarding environment problem and impact (AMDAL/AnalisisMasalahdanDampakLingkungan), though during implementation this document will often be ignored. Before the issuance of KIP permission as accordance with UU No. 23 2014, KIP mining permission was granted by regency government, in this regard was West Bangka Regency government. Some KIP have operated before this authority shifted. Hence when it shifted to province government, the permission was easier since it didn't have to pass through several other permission gates. If it's noticed here, the first actor involved is local government, either regency or province. It means that the local government involvement as upstream of KIP operation is very much.

In the case of KIP operation in Mentok waters and surrounding, resistance turmoil was relatively limited. The businessmen seems to know better that one of the ways to hush the turmoil was by providing compensation to either directly or indirectly affected society with KIP operation. Compensation choice in the form of either Corporate Social Responsibility (CSR) or the percentage fee has been the main choice to keep secure in operation. How can it connect two different interest in which it is very confrontational in many ways? It certainly needs an actor to bridge both interests. Hence it raised the term 'administrator' in the local language. This administrator is represented by government apparatus and most of them are neighborhood association (RT)/ resident association (RW) or important people respected in the society environment. The term of administrator was then the common term used by local people to describe a figure taking care of KIP and society interest. Therefore, the third actor having important role in the process to connect the two interests is administrator. Selamet (interview 12/4/2018) working as food seller in that coastal area said that the existence of administrator and compensation is to ensure KIP working in secure. Are they legal?Structurally, of course it's not. However, the process in choosing them and their activity are recognized by village and district apparatus. Wahyu, one of administrators since 2012 in an interview (13/3/2018), his election at that moment was attended by government party.

Here is the table of actors and their roles in KIP operation in Mentok waters and around it:

Table 2. Actors and their role

\begin{tabular}{|l|l|}
\hline Actor & Role \\
\hline KIP businessmen & Providing capital and manage mining \\
\hline Local government & Issue/prolong KIP permission \\
\hline Administrator & $\begin{array}{l}\text { Lobbying, negotiating, and arranging compensation } \\
\text { with coastal people }\end{array}$ \\
\hline
\end{tabular}

As the costly business unit, during this time KIP is not accessible for coastal people who are very dependent on their life from profession as fisherman or small miners. Supporting by complete permission, KIP is like unstoppable. Nevertheless, there is actually the potential operation rejection arising from society since many other areas in Bangka Island did it. The society rejection makes KIP cannot operate and must move away although they already have complete permission to operate. However, if this rejection can overcome, then KIP operation can gain much profit.

It is interesting to take a close look on general people perspective around KIP location. Most people feel grateful since they get sharing from KIP. The compensation they received making them able to think that KIP is not dangerous and disturb them. Some informants stated that KIP is not more dangerous than Rajuk Nonconventional Mining directly operated by society in the areas closer to the beach. For the people around this area, so far the short term interest is not disturbed, and thus there is no significant reason to refuse KIP, whereas there is direct benefit they gain.

Rohan, one of housewives having profession as salted fish maker, said that they were helped by KIP fund. The fishermen in the place she bought fish to process were actually going far into the middle ocean to catch fish. Therefore according to her, the fishermen were not disturbed by KIP activities. Nevertheless, she admitted that KIP could walk to the beach and very close to their houses.

"Nelayan kan jauh ke tengah nyarik ikan e. Kami dak hal dak, karena dapat kompensasi. Per KK 300 ribu. Ngambik e di masjid. Pengurus RT biasa e yang nyuruh ngambik. Tapi asak KIP e bejalan bai. Men dak, dak dapatlah. Untung merik masyarakat, men dek diprotes orang wah". (Fisherman go far away to the ocean looking for fish. We are not object since we gain 300 thousand rupiah compensation per householder. It is taken in 
mosque. Neighborhood association administrator usually asks us to take it. However, it is only if KIP operates. If it doesn't, so we don't get it. Fortunately they give, if not, the society will definitely protest.)

Similar information delivered by Sahrul (interview 13/8/2018) said that in addition to distributing compensation fund, KIP management and administrators involved society in tin sand loading-unloading, and thus in addition to receiving benefit of job opportunity, they also obtained direct fund for every householder. Different with the information delivered by Sahrul and Rohana, around KampungBaru area, Yohan (interview 12/4/2018) said that in their area, the quantity compensation they received depended on the tin produced by KIP. Rp 3,000,- per kilogram became the part from compensation so that the quantity would be different per month. Nevertheless, the same thing from every informant was that they only received compensation if KIP operated. Recently according to Yohana (interview 13/4/2018), it was started a disappointment among people as the compensation they received was getting smaller. Their suspicion was at the village apparatus and administrator dishonesty.

The information above showed that there was successfulness to positively construct KIP presence. Administrator had role to encourage people's trust that KIP gave more actual benefit to the people around KIP operation. Compensation in this regard encouraged the society to receive KIP presence. This short term pragmatism relatively didn't face meaningful resistance, although there were several minor voices of society rejecting it. This rejection, for example, was said by one of fishermen, Rujuk, who was setting a net not far from KIP operation.

\begin{abstract}
"Kami nelayan kecil ni teganggu. Duluk mudah nangkep ikan. Sekarang ni, lah berape kali ku masang jaring, lum adelah dapet e. Dulu ku pacak bejalan di pantai tu agak jauh men surut, sekarang bahaya. Lumpur e sepaha. Lah gati ku tecalep, susah berangket. Orang sine dek hiran, dapet kompensasi, tapi kami teganggu. Men pacak, pegilah jauh-jauh dari pantai ne". (We are small fishermen feeling disturbed. It's easy to catch fish in the past. Nowadays, it's already several times setting net, there's no catching at all. Last time I can walk far to the sea if tidal, now it's dangerous. Mud is as high as thigh. I am often trapped in the mud, difficult to stand up. The people here receive compensation, no wonder, but we feel disturbed. If possible, just go far away from this beach.)
\end{abstract}

Rujuk opinion was strengthen by Marzuki's (interview 13/4/2018) stating that in the past he was easy to get shrimp as the raw material to make terasi (fermented fish); however, since there's KIP around, it became difficult. Zira, Anita, and Jeha, three middle age women interviewed in KampungBaruMentok area, also said that they were surrender with this condition (interview 12/4/2018). In a glance, it seems that the ocean is not damaged; however, actually the catching area for fishermen is getting further since KIP location nowadays is previously their place to catch fish. Being a fisherman at present is not promising anymore, and thus being a tin freight worker becomes one of their choices to keep survive. Yusran, one of fishermen successfully met, stated that fish catching area is getting further and they are aware of it; however, they actually get the compensation distributed (interview 13/4/2018).
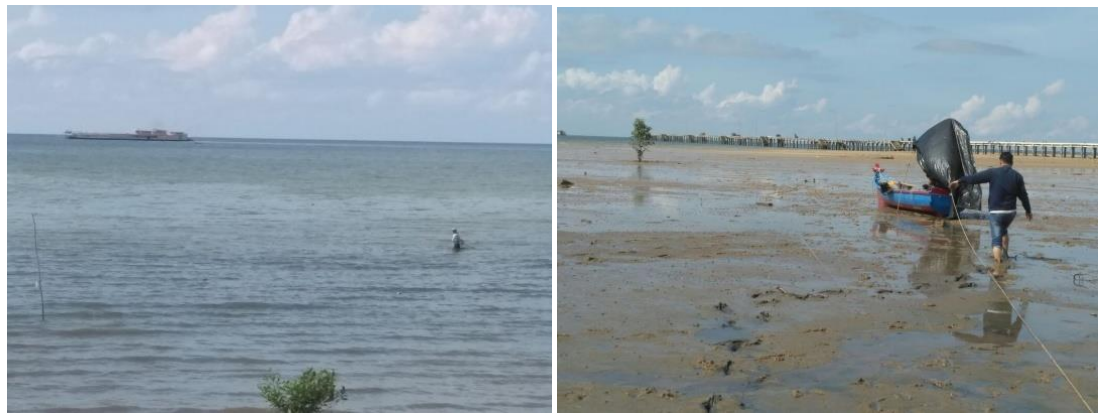

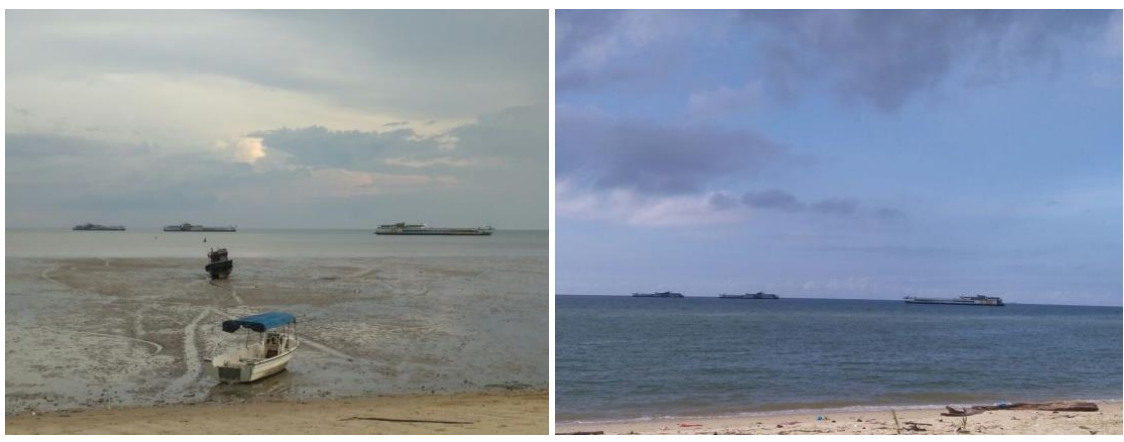

Fig 2. The irony of fisherman life and KIP activity

These minor rejections were actually meaningless. Other than outnumbered, this rejection might not also be channeled in the middle community and apparatus pragmatism that have made peace with KIP on behalf of compensation as occurred in some other regions (see Ibrahim, 2015; Ibrahim et al., 2017). One of the citizens, Sahrul (interview 13/4/2018), even said that almost all local citizens received the existence of KIP in the name of solidarity. In the case revealed by Wahyu (interview 13/4/2018), of 700 householders in his region, 6 people stated as refused. The real interest was not balanced, between making a profit in the middle of ocean damage and little compensation; a pragmatism that is not clearly and openly staged.

Below is the pragmatism relation figure between citizen and businessman:

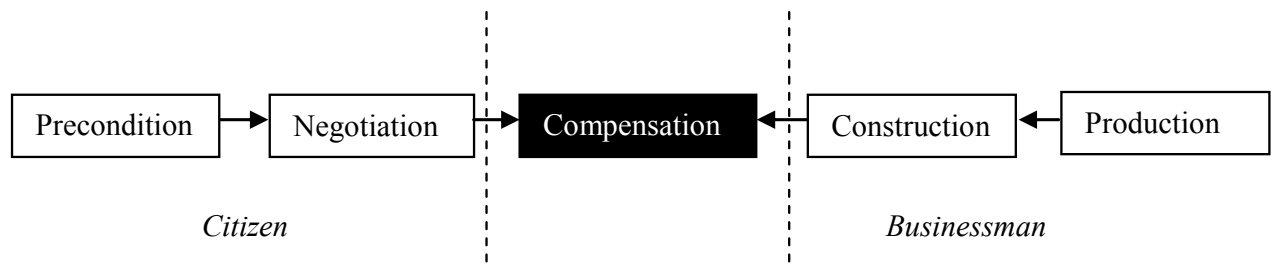

Fig 3. The pragmatism relation figure between citizen and businessman

The figure above showed that there is pre-condition on Mentok tin deposit wealth condition that was not massively exploited except by using dredge owned by PT Timah, Tbk and fisherman community working in marine sector. As KIP entered, it was then performed negotiation through administrator. The compensation became a choice. The businessman who will produce needs positive construction in order to peacefully run KIP operation and the compensation becomes the middle way.

\subsection{Apathy: Between Omission and Justification}

If we see the rejection wave on KIP operation in many other waters in Bangka Belitung Islands Province, the quiet KIP operation in Mentok coast signed that there's collective apathy. There were several arguments to explain this statement.

First, KIP operating along Mentok coastal line was so obvious. Some of them lean back and take cover; however, some other also operates openly. As the harbor region that becomes the traffic for goods and human being, the peninsula and gulf in Mentok coast are easy to see. Local government and its apparatus would understand well about KIP present. The permission process previously issued placed the government and all apparatus involved as ignoring the resulted impact. In the lowest level, village government and district were involved to supervise the process if there's problem. Wahyu (interview 13/4/2018) said that compensation distribution used neighborhood/resident association' chop. Wahyu and 
Sofyan (interview 13/4/208) even stated that apparatus were not only involved, but even also get the bigger share.

Second, society, in the name of compensation eventually felt secure with KIP. Rather than disturbed, KIP even became the vehicle to get earning without working. The way is simple: do not protest on KIP operation. Common people are like performing collective omission wrapped with support on statement of non-disturbing society directly. When there were massive resistances against KIP operation, the people along Mentok gulf and peninsula were enjoying compensation. Iyan, one of fishermen (interview 14/4/2018) clearly said: "We will resist if we don't get compensation." This condition clearly described that KIPs would be secure as far as they were able to act 'fair' by small sharing to the communities around them.

Meanwhile, the third argument was the existence of justification on KIP operation securely constructed, non-destructive, and having potential economy for the surrounding community. Reza and Sofyan, two citizens interviewed (13/4/2018) affirmed that KIP didn't destroy environment. This view was often expressed by informants on field. This construction was campaigned by the involved administrators, supported by passive position of local government on the destruction resulted from KIP. Ecological apathy was then aroused. This condition was called as omission and justification at once. As the community was collectively apathy, hence KIP kept gaining profit from the tin production operation almost without stopping. This is an ironic condition in the middle of effort to safe environment and diminishes the rising crisis.

Uniquely, one of modus used to get support from coastal community was by involving religious figures. Rohana (interview 13/4/2018) said that mosque party was usually involved in distributing compensation fund. It could be clearly seen that there's an effort to legalize KIP existence by using religion instrument as one of its reason. Ilham, one of the Mosque chief stated that "This mosque was built with many fund resources, but mostly from KIP and PT. Timah. Right now, it is being built fence from KIP."

Below does the researcher to describe on how chronic the present occurrence is simplify the apathy scheme:

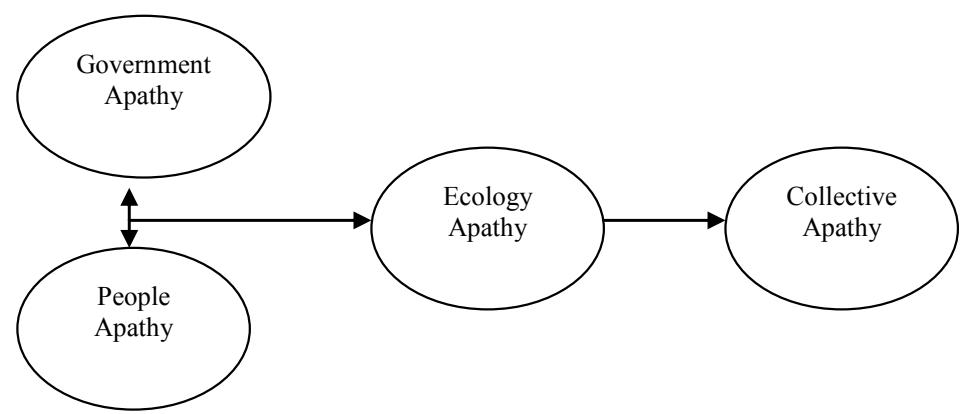

Fig 4.Collective apatism

The scheme above illustrated that collective apathy emerged from government and related stakeholders supported by community apathy toward ecology awareness. This collective apathy will result in omission and justification on the present condition.

\section{Conclusions}

Tin mining in Mentok coast area is basically supported by several key actors; they are businessmen actively looking for offshore mining locations who do not get much resistance from local people, local government issuing operation permission, and administrators in which in the middle of society are known as interest connector. KIP operation in Mentok coast West Bangka regency having relatively good level of acceptance in the middle of society is influenced by the compensation distribution from company to surrounding people in coastal area. By different quantity, cash money distribution is performed through 
local neighborhood/resident association and the mosque administrator. This compensation is given to ensure that their mining can keep operating. It is interesting that KIP operation is not even constructed disturbing although in reality, KIP destroys environment and marine biota, disturbing fisherman catching, and affecting coastal condition. In the middle of West Bangka regency capital effort to clean up as one of new regencies in Bangka Island as well the effort to push tourism sector, KIP operation feels like anomaly. This condition showed that local people actually has pragmatic attitude, peace with the ocean in which its condition has been damaged, for the sake of short term compensation. Many parties perform omission on the anomaly and as if keep looking for justification on the damage acceleration resulted from $\mathrm{KIP}$, as shown clearly by this paper.

Thank you to the Directorate ofResearch and Community Service that has funded this research in the scheme of 2018 Competency Grant. Thank you also to colleagues, students, and parties who have helped in collecting this study data, especially to Sandy Permana, RidwanDiaguna, Andy Saputra, Fajrina, Nurzaini, Abdul Rahman, and TresnaRahardja.

\section{References}

1. Chadwick, Bruce A., et al., Social Science Research Method, Translated by Sulistia, et al., IKIP Semarang Press, Semarang (1991)

2. Casley, Dennis J. and Krishna Kumar, The Collection Analysis, and Use of Monitoring and Evaluation Data, Second edition, The Johns Hopkins University Press, Maryland (1989)

3. Erman, Erwiza, From Kampong Formation to Dark Problem, Uncover Tin History in Bangka Belitung, Ombak, Yogyakarta (2009)

4. Febriyanto, Arief, et al., 2015. The Impact of Tin Mining on Squid (Urotheutischinensis) Fishing Ground in South BangkainInternational Journal of Science : Basic and Applied Research (IJSBAR), Volume 23, No.1, 283-293 (2015)

5. Haryadi D.2014. Illegal Tin Mining (Life Time Problem?), In: After 14 years (The Journey Note of Bangka Belitung Islands Province). Yogyakarta: Imperium

6. Haryadi D.2015. Criminogen Factor of Illegal Tin Mining in Bangka Belitung. Law Problems Journal UNDIP Vol 44 No 1.

7. Heidhues, Mary F. Somers, Bangka Tin andMentok Pepper, Chinese People Role in 18 th to 20th Century Bangka Island Development, Yayasan Nabil, Jakarta (2008)

8. Ibrahim, Tin in Economy Pancasila Perspective: A Case Study in Bangka Belitung Islands Province, Philosophy Doctoral Dissertation inGadjahMada University, Yogyakarta (2012)

9. Ibrahim, Bangka Tin, and The Collapse of The State Power, GSTF Journal of Law and Social Sciences, Vol. 5, Issue 1, pp.1-7 (2016)

10. Ibrahim, et al., Tin and Authority Contestation : Government, People, and Businessman in Chronic Tin Management, Proceeding of 135th, The IIER International Conference, Kyoto, Japan, 7-8 November (2017 )

11. Ibrahim, et.al., From Charm to Sorrow : The Dark Portrait of Tin Mining in Bangka Belitung, Indonesia, PEOPLE : International Journal of Social Sciences, Vol.4, Issue 1, pp. 360-382 (2018) 
12. Irawan, R. Rudy, et al., Strategic Model of Tin Mining Industry in Indonesia (Case Study of Bangka Belitung Province)inInternational Journal of Business and Management Review, Volume 2, No. 3, 48-58 (2014)

13. Marsh, David \& Gerry Stoker, Theory and Method in Political Science, Translated byHelmiMahadiandShohifullah, Nusa Media, Bandung (2010)

14. Milieudefensie, Responsible Mining Tin, Goodelectronics, Amsterdam (2016)

15. Muslih, Khairul, et al, Habitat Characteristic andMenduk River Fresh Water Fish Affected from Tin Mining in Bangka RegencyinAKUATIK-Fishery Resources Journal, Volume 8, No. 2, 17-23 (2014)

16. Rahman, Bustami, et al, Tin Problem in Babel (Several Stories and Ideas), Khomza, Yogyakarta (2011)

17. Sujitno, Sutedjo, The Impact of Indonesian Tin Throughout History, PT. GramediaPustakaUtama. Jakarta (2007)

18. Susilo, Joko\&SitiMaemunah, Three Centuries Serving the World, Bangka Belitung Tin Mining Portrait,JaringanAdvokasi Tambang (JATAM), Jakarta (2009)

19. Yunianto, Bambang, Tin Mining Problem Review in Bangka Belitung Island Province as the Input for National Tin Policy, Mineral and Coal Technology Journal Vol. 5, No. 3, July (2009)

\section{Other Sources :}

1. Law Number. 23 year 2014 regarding Local Government

2. http://www.rmolbabel.com/read/2018/04/09/8022/Kepala-DKP-Babel-PasrahLawan-28-KIP

\section{Informant List :}

1. Agus

2. Anita

3. Edi Nayo

4. Ilham

5. Iyan

6. Jeha

7. Marzuki

8. Reza

9. Rohana

10. Rujuk

11. Sahrul

12. Selamet 
13. Sofyan

14. Wahyu

15. Yuhan

16. Yusran

17. Zira 